Limnological Review (2012) 12, 4: 189-195

DOI 10.2478/v10194-012-0059-z

\title{
Definitions and evolutions of the terms "flowing and stagnant waters" in the context of the proprietorship of the lakes in Poland
}

\author{
Katarzyna Kubiak-Wójcicka' ${ }^{1}$, Michał Marszelewski ${ }^{2}$ \\ ${ }^{1}$ Faculty of Earth Sciences, Nicolaus Copernicus University, Lwowska 5, 87-100 Toruń, Poland, e-mail: kubiak@umk.pl \\ ${ }^{2}$ Faculty of Law and Administration, Nicolaus Copernicus University, Bojarskiego 3, 87-100 Toruń, Poland, \\ e-mail: marszelewski@gmail.com
}

\begin{abstract}
This article discusses the problem of property and use of waters and the legal aspects of the definitions of lakes in particular. To achieve this, the authors reviewed the acts on Water Law from 1922 up to the present day. They proved consistency in the application of the water law. From the hydrological point of view the lake belongs to stagnant waters. The definition included in the Water Law act is contrary to this depiction of the lake. The act reads that the lake may be classified as stagnant or flowing water depending upon the existence of the natural, permanent or seasonal, inflow (or outflow) of the lake. This obviously constitutes a discrepancy between the scientific and legal definition of the lake.
\end{abstract}

Keywords: flowing waters, stagnant waters, evolution of the Water Law act, lakes

\section{Introduction}

Water is the omnipresent element of our nature. It has been the fundamental element in the development of civilisation - life would have been impossible without it, its excess has destroyed and its shortage has more than once been the beginning of the end of civilisations (Kowalczak 2007).

From the hydrological point of view waters are divided into surface and groundwaters. Surface waters are divided into flowing and stagnant waters. Flowing waters are natural and man-made watercourses, and stagnant waters include lakes, marshes and artificial reservoirs.

Both stagnant and flowing waters make up water resources that are of primary economic and social importance. Polish water resources are very changeable in time and space. Hence, they are the subject of a special interest of the entire society. The rational use of Polish water resources is protected by legal regulations included in the Polish Constitution (Art. 5), and also by more detailed laws in the Water Law act.

At present, the Water Law act of 2001 is effective (Act Reg. 2001, No. 115, pos. 1229 with later amendments). It covers 10 sections. The Water Law act regu- lates the property title, conditions of the use of waters, water protection, management of water resources, water constructions, protection against floods and drought, the scope of activity of water law companies and embankment unions, and also introduces liability for damage. The Water Law act refers to well over 30 executive acts, which makes it more difficult to apply the Water Law act effectively (Szachułowicz 2007).

According to the definition in the Hydrological Dictionary (Dowgiałło et al. 2002) the Water Law act is a section of administrative law that comprises rules and norms binding in water economy.

This article discusses the question of the proprietorship of waters, use of these waters and the definitions of waters in the legal understanding. In order to achieve the objective, the authors reviewed the Water Law act since 1922 up to the present day, and pointed out consequences in water law application.

\section{Definition of the property title of lakes}

Water is the common good, they say. Can it, therefore, be one's property? The property title is mentioned in the Constitution, and its text and execution are contained in Art. 140 of the Civil Code. The 
questions of water proprietorship are of fundamental importance to water economy. The key question, however, is whether water is an object as described in Art. 45 of the Civil Code, pursuant to which material items are objects. Two features make up an object: its material character and isolation from nature. Materiality is to ensure easier differentiation of objects from other goods, and to provide an opportunity to own in a generally visible manner. On the other hand, differentiation from nature is an indispensible premise for an object to function in civil and legal terms. In the situation when water does not exist in a differentiated or individualized form, it may be considered a material object, which is not an item. Hence, the differentiation of water as a material object appears purposeful since a separate set of legal norms was developed in the form of water law (Radwański 2009). Water as an intrinsic object is not an item with respect to civil law, and proprietorship of waters, especially flowing waters, is not governed in the civil code (Paczuski 1997). Such an approach is represented by most doctrines of civil law and environmental protection law. In this case a sui juris construction is formed, which is not related to the concept of property in civil law. It is adapted to the character of the water law regulation (Wierzbowski and Rakoczy 2007).

One should bear in mind that the legislative body used the concept of property so characteristic of civil law. All the attributes described in the text and execution of the property title included in Art. 140 of the Civil Code may be applicable. An additional argument for this thesis can be seen in the premise that water is an object only when it has an isolation feature, that is when it can be found in, for example, a pond or a closed lake (Witczak and Kawałko 2009). This is a key statement for further considerations, which refers to acquiring the proprietorship of lakes in Poland.

In general, the lake is a natural depression in the earth's surface filled with water, which does not have a direct connection with the sea. This definition comes from Forel (Starmach et al. 1976). From the hydrological point of view, the lake belongs to stagnant waters exclusively. However, the definition of the lake included in the Water Law act is contrary to this concept. The act treats the lake as either stagnant or flowing water depending on the occurrence of the permanent or seasonal natural inflow or outflow of surface waters. This constitutes a contradiction between the scientific and legal definitions of the lake.

\section{Legislative status of waters}

Since Poland became independent in 1918 four acts which regulate the property title of the lakes have been introduced so far (Table 1).

In order to analyse the definitions of stagnant and flowing waters in Poland, one should return to the first Water act of 19 September 1922 (Act Reg. of 1922, No. 102, pos. 336). Adam Różański was the author of this act. The project was based upon the Austrian act of 30 May 1869, from which property relations were adopted, and the Prussian water act of 7 April 1913, which presented the issues of using waters (Mikulski 1998). Art. 1 of the Water Act of 1922 indicated that waters were either public or private. The former make up public property (a part of the common property), whereas the latter are private property. Art. 4 of the aforementioned act made the definition of private wa-

Table 1. The most important legal acts which regulate classification of lakes and their property titles

\begin{tabular}{ccl}
\hline Year & Legal basis & The approach to regulate the property titles of lakes \\
\hline 1922 & $\begin{array}{l}\text { Act Reg. of } 1922 \\
\text { No. 102, pos. } 336\end{array}$ & $\begin{array}{l}\text { The definition of the property title of a lake was not dependent upon the fact whether the lake was } \\
\text { considered stagnant or flowing water or. Each lake could be subject to the private property title. }\end{array}$ \\
1962 & $\begin{array}{l}\text { Act Reg. of } 1962 \\
\text { No. 34, pos. } 158\end{array}$ & $\begin{array}{l}\text { This act defined and nationalised the lakes to which permanent watercourses flow in or out. These } \\
\text { lakes were referred to as "flowing waters" in the act. }\end{array}$ \\
1974 & $\begin{array}{l}\text { Act Reg. of } 1974 \\
\text { No. 38, pos. } 230\end{array}$ & $\begin{array}{l}\text { The act defines lakes as "flowing waters" regardless of the type of the watercourse which flows into or } \\
\text { out of a lake. It must be assumed, therefore, that the act extended the property of the State Treasury } \\
\text { to include lakes which had not been its property in the case of seasonal watercourses. }\end{array}$ \\
& $\begin{array}{l}\text { Act Reg. of } 2001 \\
\text { The act defined a lake (as either stagnant or flowing water) depending upon the types of } \\
\text { No. 115, pos. 1229 with } \\
\text { later amendments }\end{array}$ & $\begin{array}{l}\text { watercourses (natural or man-made) flowing into or out of the lake. The lakes whose inflows and } \\
\text { outflows were of a natural origin were described as "flowing waters". }\end{array}$ \\
\hline
\end{tabular}


ters more precise. The waters listed below belonged to the proprietor of the land as long as rights acquired by other persons did not prevent it:

a) precipitation water

b) water on the proprietor's land located in lakes, ponds, pools, wells and other reservoirs, or mains, canals and ditches;

c) groundwater in the proprietor's land and springs located on the surface of their land, except for mineral springs subject to the monopoly and for waters qualified for mining reserve;

d) outflows of the above waters until they have run off into another person's land or into another person's private water or else public water.

In such a way Art. 4 p. b defined clearly that lakes could be private property. The above regulations proved that in order to determine the property title of the lake, it was not important whether the lake was considered stagnant or flowing water. Every type of lake could be a subject of the property title. In the situation when the lake was flowing water, it simply constituted the appurtenances of the land. It seems that the applied word "appurtenances" due to the specificity of the regulation itself should have been understood more commonly than that defined in Art. 51 of the present Civil Code in force.

It needs to be underlined that such a solution to the problem of the proprietorship of lakes brings associations that, regardless of their character (stagnant water, flowing water), they may have been understood to a great extent as a constituent element of landed property. This regulation is characterized by a farreaching similarity in treating water as an object in the reading of civil law and in treating the property law of waters in the legal and material categories. This issue has been discussed in the literature, and at present water is the subject of independent regulations treated separately from the property of the land.

The second chapter of the 1922 Act entitled "Use of private water by a proprietor" specified and somewhat limited the right of the land proprietor, particularly with regards to flowing waters. According to Art. 36, par. 1 "The land proprietor may dispose of water located on the surface or underground or flowing water with limitations ... as long as rights of the third party do not contradict it." One of the limitations was Art. 18, which referred directly to lake water. Pursuant to the article "The proprietor of the lake which does not belong to flowing waters cannot drain it or lower its table so much as to cause the deterioration of groundwaters of the third party unless it is necessary for regular land irrigation". Neither could the proprietor "discharge waters or other liquids into the lake, or throw into it muddy materials, which could pollute water (Art. 18, par. 2). Further restraints on the proprietorship of stagnant and flowing waters concerned, among others, bans on withholding, polluting and wasting water (Art. 22), building new or changing significantly the already existing constructions in waters (Art. 24), discharging liquids into flowing waters (Art. 25), limiting the exploitation of flowing water (Art. 37) and the obligation to drain off unused water within the borders of the proprietor's land (Art. 38). Art. 39 seems interesting: "If the proprietors of several adjacent parts of the flowing water agree on a joint execution of the rights to use the land, or they form a venture, then their lands constitute one entity as far as the execution of these rights is concerned." In justified cases the water authority could restrain or prohibit the exploitation of flowing water (Art. 23), also when water was private property (Art. 36, par. 1).

The problem concerning the proprietorship of waters in Poland is related to the introduction of the new Water Law act of 30 May 1962 (Act Reg. of 1962, No. 34, pos. 158), which in Art. 1 states that waters make up the property of the Treasury unless the act reads otherwise. Art. 1, par. 2 of the act states: "Within the limits defined by the act, the proprietorship of the land stretches over the land with stagnant surface waters and waters in the wells and ditches". Art. 2 reads that the lands with flowing surface waters within defined shore lines (that is both lakes and streams) are the property of the Treasury. This did not account for ditches. This record resulted in the takeover of the proprietorship of flowing waters and the lands located under them by the Treasury. The legislator explains what is meant by flowing and stagnant waters in Art 8 of the above act.

Flowing waters are those located in rivers, lakes or reservoirs with inflows or outflows, mountain streams, canals and other watercourses of permanent or seasonal flows, and in springs where watercourses start (Art. 8, par. 1). Stagnant waters are those found in lakes other than those defined in par. 1, in ponds and other reservoirs (Art. 8, par. 2).

As a result, the interpretation of Art.8, par.1 became arguable. A question arises whether waters in lakes or water bodies are flowing only when there is a permanent stream? This issue was considered by the Supreme Court in the justification to the decision 
of $29^{\text {th }}$ October 1981 (I CR 208/81). The Court ruled: "Pursuant to the text of Art. 8 of the Water Law of 1962 surface waters are divided into flowing waters found in rivers, lakes or water bodies with outflows and inflows, streams, canals and other watercourses of permanent flows, and into stagnant waters found in lakes other than the above mentioned, in ponds and other reservoirs. The analysis of Art. 8, par. 1 of the water law leads to the conclusion that a watercourse was used twice - in the first case it is a permanent watercourse, in the second it is a permanent or seasonal watercourse. With respect to lakes and reservoirs, it is a permanent watercourse, whereas with respect to other waters the terms: "permanent watercourse" or "seasonal watercourse" are used. The conclusion may be drawn that waters in lakes are only then flowing when they have some permanent inflow or outflow. The existence of the seasonal watercourse does not qualify such a lake as "flowing surface water". It is a very important ruling which has an influence upon the discussed law.

Another doubt referred to the definition of the watercourse. The discussed act did not specify this term. It was not known whether it was a natural or artificial watercourse, permanent or seasonal. Moreover, canals and drainage ditches, where water flows in man-made channels, were not differentiated. This means that if an artificial watercourse flows into or out of the lake (a canal or a drainage ditch), such a lake should be classified as stagnant water pursuant to the definition of the water law. According to the water law definition, both rivers and lakes or water bodies with a natural inflow or outflow are classified as flowing waters.

The act of 1962 regulated the proprietorship of lakes stating they may be an object of property only when they are stagnant waters. The classification of waters as a separate legal concept and an object of proprietorship raises another problem. This time it is the proprietorship of the land which is of decisive importance to the possibility of making stagnant surface water and waters in wells and ditches private property. The introduced legal classification of lakes (stagnant or flowing water) is different from the hydrological classification, and does not account for the functions the lakes perform in the water economy of their catchments.

Due to the character of waters, hydrology divides lakes into open and closed lakes. Open lakes let off a part of their waters in the form of a river out- flow, whereas closed lakes do not have such an outflow. Some of the lakes with an outflow may be open lakes, that is if as much water flows into it as is carried away by the river flowing out of it. In the case of the Water Law act, only if one condition is met - if the lake has an inflow or outflow - will the lake be considered flowing water. Another issue which raises doubts of a hydrological nature concerns the amount of water that flows through the lake. The amount of water flowing into the lake should be similar to the amount which flows out of it. The determination of the degree of water exchange in the lake is of considerable importance with respect to water quality and the preservation of the good condition of the ecosystem. The legislator did not specify what is meant by "other watercourses" in the 1962 water law act. Should they refer to rivulets, streams, drainage ditches or other manmade connections? The undetermined definition of a seasonal watercourse is also uncertain. Would it do if such a watercourse ran water in its bed once a year or perhaps once in several years? Hence, the lack of an accurate definition of flowing and stagnant waters, which would account for hydrological and environmental conditions of the lakes, means that the implemented regulation is hardly rational in determining the proprietorship of lakes.

By virtue of the 1962 Water Law act some of the lakes which do not raise any doubts as to whether they are flowing waters became the property of the Treasury. Firstly, the lakes of considerable importance to the management of water within the catchment were taken away. This type of takeover did not result in the right to be compensated.

A subsequent Water Law act was voted through by the Sejm on 24 October 1974 (Act Reg. No. 38 of 30 October 1974, pos. 230). Art. 1 kept the previous 1962 regulation that the State held the property title of waters unless the act stated otherwise. Pursuant to Art. 2 stagnant surface waters and waters found in wells and drainage ditches belonged to the land proprietors where they were located.

Art. 6, par. 1 introduced the concept of inland waters, and par. 2 divided these waters into surface waters and groundwaters. In turn, par. 3 divided surface waters into flowing waters (found in rivers, mountain streams, canals, other watercourses with permanent or seasonal flows, and in springs where streams start) and stagnant waters (including lakes). Yet, par. 4 stated that "the regulations on flowing waters are applicable to lakes and other water bodies from which streams 
flow in or out". Did the legislator mean permanent or seasonal watercourses? Contrary to the 1962 act, this regulation concerned lakes and other water bodies regardless of the type of watercourses (permanent or seasonal). On the grounds of the interpretation of the discussed regulation (Art. 6, par. 4 of the 1974 act) and the lack of differentiation, it must be assumed that a lake is flowing water when there is a watercourse, regardless of its type (permanent or seasonal), which flows into it or flows out of it. However, why did Art. 6, par. 3 p. 1 list permanent and seasonal watercourses with respect to other flowing waters? The failure to specify what type of watercourse is involved results in the problem of classifying lakes with seasonal watercourses as flowing or stagnant waters. This influences the question of proprietorship and, by virtue of the 1974 act, potential takeover of the lakes with seasonal watercourses.

Pursuant to Art. 2 "Stagnant surface waters and waters found in wells and ditches constitute landed property". Therefore, in the case of stagnant waters the property title of the land was the decisive criterion. In contrast, in the situation when the land was covered by state-owned flowing waters they constituted the property of the State (Art. 4), i.e. it was flowing water which determined whether land belonged to the State. However, Art 4 was not fully understood, as it ruled on state-owned flowing waters. It may have been concluded that either all flowing waters were state-owned or it referred only to state-owned flowing waters. Thus, there were also non-state flowing waters.

Doubts are adjudicated by Art. 131, par. 1 included in the transitional and final regulations, which state that: "The persons who used to be the proprietors of flowing waters taken over by the State on 12 December 1962 ...". Hence, it is proper to believe that all flowing waters were state-owned.

Art 31 of 1974 act was very important from the proprietor's point of view, whose lake was classified as flowing water. The persons who were the proprietors of flowing waters taken over by the State on 12 December 1962 and who used those waters for fishing purposes could be granted by the Poviat chief-officer a lifetime licence to use these waters for fishing purposes free of any charge. In the case of persons who could not use these waters for fishing purposes due to poor health, or if these waters were managed by statecontrolled economy units before the implementation date of the act, the Voivode could grant compensation on the principles and in the manner determined by the Cabinet of Ministers. The applications in the above cases (par. 1 and 2) were considered if they had been submitted within three years from the act implementation date, i.e. up to the end of 1977. At present, there are no grounds to assert the right to these waters and lands located under them (Osuch-Chacińska 2008).

In 1989 work on a new water law began. The new act was to account for the system transformation in Poland, including among others the regulation of the proprietorship of water resources. The bill was submitted to the Sejm on 19 April 1995. After a discussion among experts the bill was rejected in February 1997. The draft proposed the introduction of a mixed system of water proprietorship, i.e. the return to the division into public and private waters in fact. The new Water Law bill was questioned by R. Paczuski (1995), among others. He drew attention to the fact that the bill does not enforce a simple water proprietorship division into public and private waters. This act, however, did not refer to the issues on the proprietorship of flowing waters.

The new Water Law Act was passed on 18 July 2001 (Act Reg. 2001, No. 115, pos. 1229 with later amendments). The second chapter explains the issue of water proprietorship in more detail. Pursuant to Art. 5, par. 3 inland surface waters are divided into flowing and stagnant waters. Flowing waters include waters in natural watercourses, canals and springs from which watercourses start. Stagnant waters are those found in lakes and other natural water bodies not connected with natural watercourses. It means that lakes with natural inflows or outflows are classified as "flowing waters". Art. 9, par. 1 gives the definitions of a natural watercourse, a canal, and a ditch. Natural watercourses are rivers, rivulets, mountain streams and other flowing waters which flow permanently or seasonally through natural beds. Canals are man-made channels which carry water in a permanent or seasonal manner. Their bed is at least $1.5 \mathrm{~m}$ wide at their mouth and capture. Ditches, on the other hand, are man-made troughs which carry water in a permanent or seasonal manner. Their bed width is less that $1.5 \mathrm{~m}$ at their mouth. The laws on flowing waters are applicable to lakes and other water bodies with a permanent inflow or outflow of surface waters, as well as waters found in artificial water reservoirs situated on flowing waters (Art. 5, par 4).

Art. 10 states that waters can be the property of the Treasury, other legal entities or individual persons. Waters belonging to the Treasury or territorial 
self-government units constitute public waters. This means that lakes with natural inflows or outflows cannot be the property of entities other than the Treasury or territorial self-government units (Art. 10, par. 2). Public flowing waters are not subject to civil law circulation apart from the cases defined in the act (Art. 10, par. 3). Therefore, such waters are absolutely excluded from circulation. Civil law circulation means not only disposing of the property title but also encumbering this law with another legal form, which leads to using someone else's property (Szachułowicz 2010).

The Water Law does not see the regulation of the watercourse as a change of its character - it is still a natural watercourse. Yet, if a lake is artificially connected with other lakes or watercourses in the form of ditches or canals, then the lake is stagnant water. Stagnant waters and waters in ditches which are located within the borders of the property constitute landed property (Art. 12), and may be sold.

The regulation concerning lake proprietorship can be found in Art. 12, par. 1 of the discussed act. "Stagnant waters and waters in ditches located within the borders of the landed property constitute the property of the owner". Despite the "cosmetic" change to the law (Art. 2 of the Act of 1974) the legal consequences are the same. This law determines the relation between the proprietorship of the land and the proprietorship of stagnant water according to the rule: if the land belongs to a proprietor, so does the water. In the case of flowing surface water it is the contrary. Here the public property and property of water transfer into the proprietorship of the land under the water. This relation between the land and the flowing water results from the rule that flowing water constitutes a separate object of property according to the statutory regulation (Szachułowicz 2010). Hence, it is flowing surface waters that determine the proprietorship of the land under the water, whereas it is the lands under stagnant waters that determine the proprietorship of the water.

In the later period changes were introduced into the Water Law act of 2001. At present the definition of flowing waters is based upon the amended Water Law Act of 2001 (Act Reg. of 2012, pos. 145, 951). Inland surface waters are divided into the following:

1) flowing waters which include waters:

a) in natural watercourses, canals and springs from which watercourses start

b) found in lakes and other natural water bodies with a permanent or seasonal natural inflow or outflow of surface waters

c) found in artificial water reservoirs situated on flowing waters

2) stagnant waters, which include waters found in lakes and other natural water bodies not connected directly in a natural way with flowing surface waters.

The regulations on stagnant waters are applicable to the waters located in the depressions of the terrain, not ponds formed as a result of human activity (Art. 5).

The issue of water proprietorship returned in 2007 when the act of 7 September 2007 on the disclosure of property titles belonging to the Treasury and territorial self-government units listed in the proprietorship registers came into force (Act Reg. of 2007, No. 191, pos.1365 with later amendments). On the grounds of Art. 2 the appropriate authorities are obliged within 12 months from the act's effective date to submit applications to the appropriate district courts to disclose the property titles in the proprietorship registers. Thus, in the situation when the lake is considered flowing water, no matter who the proprietor in the proprietorship registers is, the relevant authorities must submit a required application which would result in the entry into the proprietorship registers, which would mean acquiring the property title of the land and lake by the Treasury.

The discussed act forced the regulation of the issue of the Treasury's proprietorship (including lakes) and led to numerous court cases on various grounds, e.g. acquired through bequest and approved by the court or purchased (certified by a notary), they were considered private property.

\section{Final remarks}

The property title of waters has not been settled since the introduction of the water law in 1962. This regulation reflected the existing political situation and socialist economy of the country, which assumed the abolition of the private proprietorship of lakes classified as flowing waters.

The present state results from long-lasting ignorance and classification of lakes into stagnant and flowing waters in the Water Law act. From the hydrological point of view it is an artificial classification, which does not reflect the actual condition. The accepted definitions in the water law treat the proprietorship of lakes in a very sketchy way, which results 
from the solutions already existent in socialism. Individual persons or legal entities are still inscribed into the proprietorship registers as the proprietors of the land located under surface flowing waters (mainly lakes). The disclosure of the state of the property titles of the Treasury commenced as a result of the regulation in 2007, and has lasted up to now. It is still not known how many persons the problem of the 1962 act concerns. At present there are at least a dozen or so court cases concerning the proprietorship of lakes.

Regardless of what viewpoint is adopted in the case of the proprietorship of lakes, there must be a dialogue between lawyers and hydrologists. Shared discussions and decisions should make legal regulations function in accordance with the hydrological classification of lakes and the country's existing economic and political situation. In the light of the presented arguments it seems vital that laws should be adapted to the specificity of the subject of their regulation, and should not collide with one another or with the entire legal system.

\section{References}

Dowgiałło J., Kleczkowski A.S, Macioszczyk T., Różkowski A. (eds), 2002, Słownik Hydrogeologiczny (Dictionary of Hydrogeology), PIG, Warszawa, p. 461 (in Polish).

Kowalczak P., 2007, Konflikty o wodę (Water conflicts), Wyd. Kurpisz, Przeźmierowo, p. 480 (in Polish).
Mikulski Z., 1998, Gospodarka wodna (Water management), PWN, Warszawa, p. 202 (in Polish).

Osuch-Chacińska L., 2008, Zasób nieruchomości Skarbu Państwa w gospodarce wodnej (State Treasury's resource of real estate in water management), Gosp. Wod. 3: 98-101 (in Polish).

Paczuski R., 1995, Opinia do projektu ustawy Prawo Wodne. Ekspertyza nr 52 (Opinion to the draft on Water Law. Expertise No. 52) [Manuscript], Kancelaria Sejmu, Biuro Studiów i ekspertyz, Warszawa, p. 11 (in Polish).

Paczuski R., 1997, Potrzeby i problemy reformy polskiego prawa wodnego (Needs and problems of Polish water law reform), [in:] Bączyk M. (ed.), Księga pamiątkowa ku czci Profesora Leopolda Steckiego (Memorial book in honour of Professor Leopold Stecki), TNOiK „Dom Organizatora", Toruń: 645-659 (in Polish).

Radwański Z., 2009, Prawo cywilne - część ogólna (Civil law - general part), C.H. Beck, Warszawa, p. 369 (in Polish).

Starmach K., Wróbel S., Pasternak K., 1976, Hydrobiologia (Hydrobiology), PWN, Warszawa, p. 621 (in Polish).

Szachułowicz J., 2007, Prawo wodne. Komentarz (Water law. Commentary), LexisNexis, Warszawa, s. 433 (in Polish).

Szachułowicz J., 2010, Prawo wodne. Komentarz (Water law. Commentary), LexisNexis, Warszawa, p. 504 (in Polish).

Wierzbowski B., Rakoczy B., 2007, Podstawy prawa ochrony środowiska (Fundamentals of environmental law), LexisNexis, Warszawa, p. 325 (in Polish).

Witczak H., Kawałko A., 2009, Prawo rzeczowe (Property law), C.H. Beck, Warszawa, p. 209 (in Polish). 